\title{
Body Morphometry in Relation to Season, Sex and Body Weight in Vrindavani Calves
}

\author{
Sikander Shabab Khan ${ }^{1 *}$, Triveni Dutt ${ }^{2}$, Amit Kumar $^{3}$, Brijesh Patel ${ }^{1}$, Mukesh Singh ${ }^{1}$, \\ Pratik R. Wankhade ${ }^{1}$, Upender Singh ${ }^{1}$ and G. K. Gaur ${ }^{1}$
}

${ }^{1}$ Livestock Production Management (LPM), ICAR-Indian Veterinary Research Institute

(IVRI), Izatnagar, Bareilly - 243122 (U.P.), India

${ }^{2}$ ICAR-IVRI, Izatnagar, Bareilly, India

${ }^{3}$ Division of Animal Genetics \& Breeding, ICAR-IVRI, Izatnagar, Bareilly, India

*Corresponding author

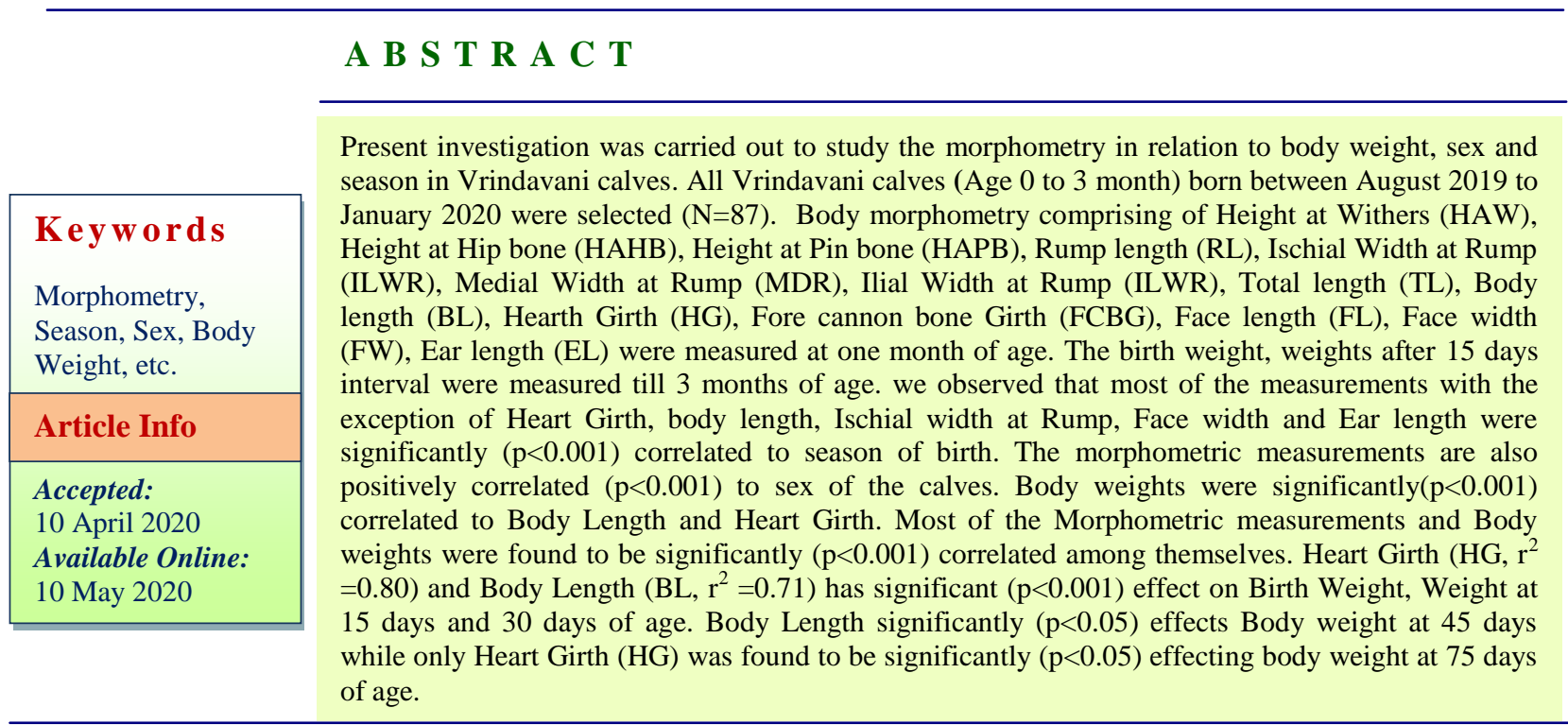

\section{Introduction}

Live weight (LW) forms the basis for a number of research and management practices including evaluation of growth rates, animal responsiveness to different feeds and environmental factors, and determination of diet requirements. In breeding programs for traits, notably weights and weight gains obtained at different ages, are considered as selection criteria since these traits are easy to obtain and are positively correlated to other traits of economic interest. These traits respond to selection by showing heritability estimates of medium magnitude (Boligon et al., 2011). 
Precise measurement of livestock body weight is important in deciding the weight of slaughter, the amount of feeding and what dose of treatment to use (Machila et al., 2008). In addition, knowledge of animal weight and weight changes are also important in determining responses to genetic selection (Touchberry and Lush., 1998), and are a key management tool (Dingwell et al., 2006; Ozkaya and Bozkurt., 2009). A weighing scale is considered the gold standard among the many methods used to assess it, if the scales used are well configured (Machila et $a l ., 2008)$. Calves are the future replacement stocks. In the calf rearing, the key management objective is to ensure that calves survive and remain healthy (Jozica et al., 2012).However, most of the rural farmers may be restricted by lack of technical skills in the operation and maintenance of facilities required for weight measuring (Dingwell et al., 2006; Kashoma et al., 2011; Musa et al., 2011).Farmers and cattle traders are not accurate in estimating cattle Live Weight, with 46 per cent underestimates and 25 per cent overestimates reported (Machila et al., 2008). Body measurements used to predict Live body weight can have a direct and indirect effect on its determination (Yakubu et $a l ., 2012$ ). Heart Girth is generally accepted as the most satisfactory single predictor of live weight in cattle since it is closely related to body weight (Lesosky et al., 2012; Lukuyu et al., 2016).

Morphometric traits measurements can be a vital tool for local farmers to make decisions of selection and breed improvement (Salim bhashwan., 2014). Using morphometric traits to predict live body weight may be important for local famers to make selection and cull decisions, as it can be a relatively low cost, high accuracy and consistency (Musa et al., 2011). In some cases, morphometric characteristics can be more accurate than modern weighing machines, as the latter may provide skewed measurements induced by fullness of the gut (Obike et al., 2010). Keeping in view the problem of dairy calf selection at the farm level at an early stage, the present study was undertaken to investigate relationship between morphometric measurement at one-month age with sex and body weights of calves born in different seasons.

\section{Materials and Methods}

Location and Climatic conditionsThe farm is located at an altitude of $169.2 \mathrm{~m}$ above sea level, at north latitude of $28^{0} 22^{\prime}$ and east longitude of $79^{0} 24^{\prime}$. This place falls in India's upper Gangetic Plain Region. It usually has a humid subtropical climate with high temperature differences between summer and winter. Summers are long, with the monsoon season in between, from early April until October. Winter starts in October and approaches peaks in January. The extreme temperatures fluctuate between $4^{\circ} \mathrm{C}$ and $44^{\circ}$ C. The mean annual temperature is $25^{\circ} \mathrm{C}(77$ $\circ \mathrm{F}$ ), and the mean monthly temperatures range from $14^{\circ} \mathrm{C}$ to $33^{\circ} \mathrm{C}\left(58^{\circ} \mathrm{F}\right.$ to $\left.92^{\circ} \mathrm{F}\right)$. The average annual rainfall is about $1714 \mathrm{~mm}$ (28.1 inches), the bulk of which occurs during the July and August monsoon.

\section{Experimental animals}

All Vrindavani calves (Age 0 to 3 month) born between August 2019 to January 2020 were selected. During this period approximate 87 calves were born. Body morphometry comprising of Height at different body points, Length and width of superficial body parts. Hearth Girth(HG), Forecannon bone Girth (FCBG), Face length(FL), Face width (FW), Ear length(EL) were measured using measuring tape and Locally made Height scale at 30 days of age. The birth weight, weight after 15 days interval was measured till 3 months of age. 


\section{Health and hygiene practices}

All of the calves were reared during the entire study period under strict management and proper hygienic conditions. During the calf's second week of age de worming and disbudding was completed. During the time of experimentation good sanitation of the pens, feeding utensils, water containers and surrounding experimental area has been preserved. The pens were cleaned daily, and all hygienic precautions were taken to prevent infectious and contagious diseases from occurring.

\section{Housing of calves}

The calves were housed individually in well ventilated, clean and dry cemented concrete pens for 18 hours (from $3.00 \mathrm{pm}$ to $9.00 \mathrm{am}$ ) throughout the experimental periods. They were let loose for 6 hours (9.00am to 3.00 pm) daily in open paddock for exercise and also to facilitate washing, cleaning and drying of calf pens. Free access to fresh, clean and wholesome water along with green fodder was given to the calves.

\section{Feeding schedule of calves}

After colostrum feeding the calves were maintained on whole milk. Calf starter and roughage was provided adlib from second weeks onwards. The feeding schedule of the calves is presented in table 1 .

\section{Parameters recorded}

\section{Production parameters}

The calves were weighed at birth (W1) and subsequently weighed after each 15 days till 3 months of age. The weight were designated as W1(weight at $15^{\text {th }}$ day),W2(weight at $30^{\text {th }}$ day),W3(weight at $45^{\text {th }}$ day), W4 (weight at $60^{\text {th }}$ day),W5(weight at $75^{\text {th }}$ day), W6(weight at $90^{\text {th }}$ day.
The morphometry of the animal was measured at 30 days of age. The morphometry comprises of Height at Withers(HAW), Height at Hip bone(HAHB), Height at Pin bone(HAPB), Rump length(RL), Ischial Width at Rump(ILWR), Medial Width at Rump(MDR), Ilial Width at Rump(ILWR), Total length(TL), Body length(BL), Hearth Girth(HG), Fore cannon bone Girth (FCBG), Face length(FL), Face width $(\mathrm{FW})$, Ear length(EL). The definition of body morphometry is given as per Table 2 .

\section{Statistical analysis}

The information collected by data sheet would be pooled and analyzed as per standard statistical procedure (Snedecor and Cochran, 1989). Statistical analysis was done by appropriate method with SAS Enterprize guide 4.3.

\section{Results and Discussion}

The mean $\pm \mathrm{SD}$, mode and range of different body morphometric measurements and weights is given in Table 3. Correlation of body morphometry is given in Table 4 . The body morphometric measurements are correlated to season of birth of Calves. However, most of the measurements with the exception of Heart Girth, Body length, Ischial width at Rump, Face width and Ear length were correlated to season at $0.01 \%$ level.

In earlier findings, the effect of season on morphometry was limited to body length and pre-weaning relative gain (Karna et al., 2001). The correlation of BW with $\mathrm{HG}$ at various ages for Tanzania Shorthorn Zebu cattle were in the range of 0.65-0.94 (Kashoma et al., 2011). The morphometric measurements are also positively correlated $(\mathrm{p}<0.001)$ to sex of the calves with the exception of Ilial width at Rump, Ischial width at Rump, Ear length and Fore cannon bone girth. 
Table.1 Feeding schedule of the calves at calf section of IVRI

\begin{tabular}{|l|c|l|}
\hline Days & Colostrum & Whole milk \\
\hline $\mathbf{0 - 3}$ & $1 / 10^{\text {th }}$ Colostrum & \\
\hline $\mathbf{4 - 5 6}$ & - & $1 / 10^{\text {th }}-$ of BW \\
\hline $\mathbf{5 7 - 6 3}$ & - & $1 / 20^{\text {th }}$ of BW \\
\hline $\mathbf{6 4 - 7 2}$ & - & $1 / 40^{\text {th }}$ of BW \\
\hline
\end{tabular}

Table.2 Definitions of body measurements (Rana et al., 2009)

\begin{tabular}{|c|c|c|}
\hline S.No. & Morphometric trait & Description \\
\hline 1 & Height at wither (HAW) & $\begin{array}{l}\text { Vertical distance from ground to the highest point } \\
\text { of the Withers. }\end{array}$ \\
\hline 2 & Body length (BDL) & $\begin{array}{l}\text { Oblique distance between tip of the Shoulder to } \\
\text { the tip of the Pin bone. }\end{array}$ \\
\hline 3 & Heart girth (HG) & $\begin{array}{l}\text { Circumference of chest just behind the point of } \\
\text { Elbow. }\end{array}$ \\
\hline 4 & Face length (FL) & Distance between polls to upper edge of Muzzle. \\
\hline 5 & Face width (FW) & Maximum distance between both the Eyes. \\
\hline 6 & Ear length (EL) & $\begin{array}{l}\text { Length of lower surface of Ear measured from tip } \\
\text { to junction of Ear to Face. }\end{array}$ \\
\hline 7 & $\begin{array}{l}\text { Fore cannon bone girth } \\
\text { (FCBG) }\end{array}$ & Circumference of left Cannon bone in the middle. \\
\hline 8 & Height at hipbone (HAHB) & $\begin{array}{l}\text { Vertical distance from ground to the highest point } \\
\text { of Hip bone. }\end{array}$ \\
\hline 9 & Height at pin bone (HAPB) & $\begin{array}{l}\text { Vertical distance from ground tothe highest point } \\
\text { of Pin bone. }\end{array}$ \\
\hline 10 & Rump slope (RS) & $\begin{array}{l}\text { Difference of height at Hipbone and height at Pin } \\
\text { bone. }\end{array}$ \\
\hline 11 & Rump length(RL) & $\begin{array}{l}\text { Distance between the tip of the Ilium and the tip } \\
\text { of the Ischium. }\end{array}$ \\
\hline 12 & $\begin{array}{l}\text { Ischium Width of the Rump } \\
\text { (ISWR) }\end{array}$ & $\begin{array}{l}\text { Measured between the two tips of the } \\
\text { Ischium(Pinbones). }\end{array}$ \\
\hline 13 & $\begin{array}{l}\text { Ilium width of the rump } \\
\text { (ILWR) }\end{array}$ & $\begin{array}{l}\text { Measured between the two tips of the Ilium } \\
\text { (Hipbones). }\end{array}$ \\
\hline 14 & $\begin{array}{l}\text { Medium width of rump } \\
\text { (MWR) }\end{array}$ & $\begin{array}{l}\text { Measured between the trochanter (coxofemoral } \\
\text { articulation). }\end{array}$ \\
\hline 15 & Top line (TPL) & $\begin{array}{l}\text { It is the total length of the animal from the front } \\
\text { of the poll to the back of the Rump. }\end{array}$ \\
\hline
\end{tabular}


Table.3 Mean, Mode and Range of Morphometric measurements and Body Weights

\begin{tabular}{|l|r|r|r|}
\hline Variable & Mean \pm SE & Mode & Range \\
\hline HAW $(\mathrm{cm})$ & $69.83 \pm 0.73$ & 67.82 & 32.00 \\
HAHB $(\mathrm{cm})$ & $72.64 \pm 0.80$ & 69.60 & 33.53 \\
HAPB $(\mathrm{cm})$ & $67.71 \pm 0.75$ & 64.01 & 51.56 \\
RL $(\mathrm{cm})$ & $21.91 \pm 0.29$ & 21.08 & 14.73 \\
ILWR(cm) & $16.21 \pm 0.33$ & 14.48 & 16.26 \\
MDR $(\mathrm{cm})$ & $19.16 \pm 0.27$ & 18.29 & 12.70 \\
ISWR(cm) & $11.78 \pm 0.15$ & 10.67 & 6.86 \\
TL $(\mathrm{cm})$ & $89.55 \pm 1.45$ & 83.82 & 66.04 \\
BL(cm) & $94.85 \pm 1.23$ & 85.60 & 58.33 \\
HG(cm) & $96.58 \pm 1.28$ & 74.65 & 63.18 \\
FCBG(cm) & $11.56 \pm 0.11$ & 9.14 & 86.11 \\
FL(cm) & $19.82 \pm 0.40$ & 17.78 & 14.48 \\
FW(cm) & $13.46 \pm 0.22$ & 12.95 & 10.16 \\
EL(cm) & $13.22 \pm 0.12$ & 12.95 & 5.08 \\
birth wt.(Kg) & $21.22 \pm 0.44$ & 24.00 & 24.00 \\
W1(Kg) & $23.30 \pm 0.46$ & 22.00 & 19.00 \\
W2(Kg) & $26.85 \pm 0.48$ & 26.00 & 24.00 \\
W3(Kg) & $30.74 \pm 0.66$ & 30.00 & 34.00 \\
W4(Kg) & $36.53 \pm 0.88$ & 32.00 & 36.00 \\
W5(Kg) & $43.57 \pm 1.19$ & 42.00 & 41.00 \\
W6(Kg) & $49.65 \pm 1.76$ & 42.00 & 42.00 \\
\hline
\end{tabular}

Table.4.1 Correlation between Morphometric measurements and other parameters

\begin{tabular}{|l|l|l|l|l|l|l|l|l|l|}
\hline Morphometry & season & sex & $\begin{array}{l}\text { Birth } \\
\text { weight }\end{array}$ & W1 & W2 & W3 & W4 & W5 & W6 \\
\hline HAW & $0.31^{\mathrm{a}}$ & $0.25^{\mathrm{c}}$ & 0.13 & 0.18 & 0.12 & 0.17 & 0.22 & 0.10 & -0.05 \\
\hline HAHB & $0.37^{\mathrm{a}}$ & $0.38^{\mathrm{a}}$ & 0.14 & 0.13 & 0.15 & 0.15 & 0.16 & 0.07 & -0.12 \\
\hline HAPB & $0.35^{\mathrm{a}}$ & $0.30^{\mathrm{b}}$ & 0.11 & 0.15 & 0.10 & 0.12 & 0.13 & 0.03 & -0.15 \\
\hline RL & $0.22^{\mathrm{c}}$ & $0.23^{\mathrm{c}}$ & 0.09 & 0.07 & 0.05 & 0.10 & 0.15 & 0.09 & 0.09 \\
\hline ILWR & $0.26^{\mathrm{c}}$ & 0.20 & -0.01 & -0.01 & 0.00 & 0.09 & 0.15 & 0.13 & 0.10 \\
\hline MDR & $0.30^{\mathrm{a}}$ & $0.3^{\mathrm{b}}$ & 0.14 & 0.20 & 0.18 & 0.23 & $0.29^{\mathrm{c}}$ & 0.22 & 0.11 \\
\hline ISWR & 0.09 & 0.08 & 0.16 & 0.01 & 0.01 & 0.07 & 0.22 & 0.21 & 0.20 \\
\hline TL & 0.09 & $0.36^{\mathrm{a}}$ & 0.09 & 0.14 & 0.14 & 0.21 & $0.27^{\mathrm{c}}$ & 0.16 & -0.02 \\
\hline BL & -0.02 & 0.12 & $0.74^{\mathrm{a}}$ & $0.77^{\mathrm{a}}$ & $0.61^{\mathrm{a}}$ & $0.42^{\mathrm{a}}$ & $0.41^{\mathrm{b}}$ & $0.29^{\mathrm{c}}$ & 0.00 \\
\hline HG & -0.13 & 0.14 & $0.82^{\mathrm{a}}$ & $0.72^{\mathrm{a}}$ & $0.63^{\mathrm{a}}$ & $0.52^{\mathrm{a}}$ & $0.45^{\mathrm{c}}$ & $0.32^{\mathrm{c}}$ & 0.00 \\
\hline FCBG & $0.22^{\mathrm{c}}$ & -0.12 & 0.15 & 0.10 & -0.01 & 0.01 & 0.04 & 0.01 & 0.05 \\
\hline FL & $0.22^{\mathrm{c}}$ & $0.25^{\mathrm{c}}$ & -0.003 & 0.01 & 0.006 & 0.07 & 0.16 & 0.07 & -0.02 \\
\hline FW & 0.20 & $0.33^{\mathrm{b}}$ & 0.09 & 0.19 & 0.1 & 0.16 & 0.14 & 0.03 & -0.18 \\
\hline EL & 0.03 & -0.06 & 0.14 & 0.11 & 0.06 & 0.08 & 0.17 & 0.18 & 0.37 \\
\hline
\end{tabular}

Significant Correlation at a, $0.1 \%$ and $\mathrm{b}, 1 \%$ and c,5\% respectively 
Table.4.2 Correlation among Morphometric measurements

\begin{tabular}{|l|l|l|l|l|l|l|l|l|l|l|l|l|l|}
\hline & $\begin{array}{l}\text { HA } \\
\mathbf{W}\end{array}$ & $\begin{array}{l}\text { HAH } \\
\mathbf{B}\end{array}$ & $\begin{array}{l}\text { HAP } \\
\mathbf{B}\end{array}$ & $\mathbf{R L}$ & $\begin{array}{l}\text { ILW } \\
\mathbf{R}\end{array}$ & $\begin{array}{l}\text { MD } \\
\mathbf{R}\end{array}$ & $\begin{array}{l}\text { ISW } \\
\mathbf{R}\end{array}$ & $\mathbf{T L}$ & $\mathbf{B L}$ & $\mathbf{H G}$ & $\begin{array}{l}\text { FCB } \\
\text { G }\end{array}$ & FL & FW \\
\hline HAW & 1 & - & - & - & - & - & - & - & - & - & - & - & - \\
\hline $\begin{array}{l}\text { HAH } \\
\text { B }\end{array}$ & $0.79^{\mathrm{a}}$ & 1 & - & - & - & - & - & - & - & - & - & - & - \\
\hline HAPB & $0.73^{\mathrm{a}}$ & $0.53^{\mathrm{a}}$ & 1 & - & - & - & - & - & - & - & - & - & - \\
\hline RL & $0.87^{\mathrm{a}}$ & $0.75^{\mathrm{a}}$ & $0.54^{\mathrm{a}}$ & 1 & - & - & - & - & - & - & - & - & - \\
\hline ILWR & $0.85^{\mathrm{a}}$ & $0.80^{\mathrm{a}}$ & $0.57^{\mathrm{a}}$ & $0.88^{\mathrm{a}}$ & 1 & - & - & - & - & - & - & - & - \\
\hline MDR & $0.88^{\mathrm{a}}$ & $0.82^{\mathrm{a}}$ & $0.57^{\mathrm{a}}$ & $0.89^{\mathrm{a}}$ & $0.90^{\mathrm{a}}$ & 1 & - & - & - & - & - & - & - \\
\hline ISWR & $0.66^{\mathrm{a}}$ & $0.60^{\mathrm{a}}$ & $0.53^{\mathrm{a}}$ & $0.66^{\mathrm{a}}$ & $0.73^{\mathrm{a}}$ & $0.73^{\mathrm{a}}$ & 1 & - & - & - & - & - & - \\
\hline TL & $0.82^{\mathrm{a}}$ & $0.75^{\mathrm{a}}$ & $0.55^{\mathrm{a}}$ & $0.84^{\mathrm{a}}$ & 0.87 & $0.88^{\mathrm{a}}$ & $0.64^{\mathrm{a}}$ & 1 & - & - & - & - & - \\
\hline BL & 0.12 & 0.14 & 0.09 & 0.14 & 0.05 & 0.18 & 0.20 & 0.12 & 1 & - & - & - & - \\
\hline HG & 0.11 & 0.03 & $0.23^{\mathrm{c}}$ & 0.03 & -0.03 & 0.07 & 0.11 & 0.10 & $0.64^{\mathrm{a}}$ & 1 & - & - & - \\
\hline FCBG & 0.16 & 0.08 & $0.02^{\mathrm{a}}$ & 0.03 & -0.02 & 0.07 & 0.05 & -0.02 & 0.14 & 0.12 & 1 & - & - \\
\hline FL & $0.86^{\mathrm{a}}$ & $0.74^{\mathrm{a}}$ & $0.70^{\mathrm{a}}$ & $0.81^{\mathrm{a}}$ & $0.90^{\mathrm{a}}$ & $0.84^{\mathrm{a}}$ & $0.72^{\mathrm{a}}$ & 0.85 & 0.06 & 0.00 & 0.03 & 1 & - \\
\hline FW & $0.89^{\mathrm{a}}$ & $0.74^{\mathrm{a}}$ & $0.67^{\mathrm{a}}$ & $0.83^{\mathrm{a}}$ & $0.79^{\mathrm{a}}$ & $0.83^{\mathrm{a}}$ & $0.53^{\mathrm{a}}$ & 0.78 & 0.09 & 0.08 & 0.00 & $0.80^{\mathrm{a}}$ & 1 \\
\hline EL & 0.19 & 0.09 & 0.08 & $0.25^{\mathrm{c}}$ & $0.18^{\mathrm{c}}$ & $0.24^{\mathrm{c}}$ & $0.23^{\mathrm{c}}$ & 0.15 & 0.13 & 0.16 & -0.12 & 0.19 & 0.13 \\
\hline Signis
\end{tabular}

Significant Correlation at $(\mathrm{a}, 0.1 \%),(\mathrm{b}, 1 \%)$ and $(\mathrm{c}, 5 \%)$ respectively

Table.4.3 Correlation among Body Weights

\begin{tabular}{|l|l|l|l|l|l|l|}
\hline & Birth wt. & W1 & W2 & W3 & W4 & W5 \\
\hline Birth wt. & - & - & - & - & - & - \\
\hline W1 & $0.88^{\mathrm{a}}$ & - & - & - & - & - \\
\hline W2 & $0.75^{\mathrm{a}}$ & $0.88^{\mathrm{a}}$ & - & - & - & - \\
\hline W3 & $0.62^{\mathrm{a}}$ & $0.77^{\mathrm{a}}$ & $0.91^{\mathrm{a}}$ & - & - & - \\
\hline W4 & $0.57^{\mathrm{a}}$ & $0.73^{\mathrm{a}}$ & $0.85^{\mathrm{a}}$ & $0.93^{\mathrm{a}}$ & - & - \\
\hline W5 & $0.43^{\mathrm{b}}$ & $0.60^{\mathrm{a}}$ & $0.76^{\mathrm{a}}$ & $0.87^{\mathrm{a}}$ & $0.93^{\mathrm{a}}$ & - \\
\hline W6 & 0.04 & 0.18 & $0.42^{\mathrm{c}}$ & $0.66^{\mathrm{b}}$ & $0.78^{\mathrm{a}}$ & $0.91^{\mathrm{a}}$ \\
\hline
\end{tabular}

Significant Correlation at (a, $0.1 \%),(\mathrm{b}, 1 \%)$ and (c, 5\%) respectively.W1(weight at $15^{\text {th }}$ day),W2(weight at $30^{\text {th }}$ day), W3 (weight at $45^{\text {th }}$ day), W4 (weight at $60^{\text {th }}$ day), W5 (weight at $75^{\text {th }}$ day), W6 (weight at $90^{\text {th }}$ day

There is also positive correlation among most of morphometric measurements and body weights as shown in Table 3 and 4. Analysis of variance reveals that Heart Girth $\left(\mathrm{HG}, \mathrm{r}^{2}\right.$ $=0.80)$ and Body Length $\left(\mathrm{BL}, \mathrm{r}^{2}=0.71\right)$ has significant $(\mathrm{p}<0.001)$ effect on Birth Weight, Weight at 15 days and 30 days of age. However, Body Length significantly $(\mathrm{p}<0.05)$ effects Body weight at 45 days. Subsequently weight at 60 and 90 days of age is not effected by one month morphometric measurements while at 75 days, only Heart Girth (HG) was found to be significantly ( $\mathrm{p}<0.05)$ effecting body weight.
The birth weight significantly $(\mathrm{p}<0.001)$ effects future milk production in Iranian Holstein calves (Ghoraishy and Rokouei., 2013). In addition, calves with higher birth weight have higher growth rate compared to those with lower birth weight (Boligon et al., 2010; Coffey et al., 2006).

Furthermore, calves with higher body weight had higher persistency than low body weight calves (Lamb and Barker., 1975). However in Egyptions Buffaloes calf body weight between $30-50 \mathrm{~kg}$ had no significant $(\mathrm{p}<0.05)$ effect on milk yield (Hamad and Moghazy, 
2015) while in Holstein calves, birth weight between 20 and $60 \mathrm{~kg}$ significantly effects 305 days Milk yield (Rahbar el al., 2016). Birth weight is a better indicator of growth after weaning than is rate of growth to weaning at $500 \mathrm{Ibs}$. Birth weight has an even higher relationship with days from birth to 900 pounds body weight (Dawsen et al., 1947).

From the above experiment, it can be said that out of all the morphometric measurements heart girth and body length directly affect body weight of the calves. Similar results were also reported in Dhofari calves where Heart Girth was found to be significantly $(\mathrm{p}<0.05)$ correlated $(\mathrm{r}=0.957)$ to live body weight. (Salim Bahashwan., 2014).

In conclusion, information on morphometry is vital and valuable in management and breeding programs and should be well utilized to improve the performance of Vrindavani cattle breeds. Heart Girth appears to be a highly specific indicator of body weight since it was more likely to influence body weight at later ages. However, Body Length is also associated to weight at some point of time during early life. For this reason, body morphometrical measurements are useful to identify animals with rapid gain ability. These measurements could be integrated into future studies of prediction of body weight in relation to season and sex so that animals can be selected at an earlier stage.

\section{References}

Boligon, A.A., M. E. Z. Mercadante, S. Forni, R. B. L. Lobo and Albuquerque, G. 2010. Covariance functions for body weight from birth to maturity in Nellore cows. Journal of Animal Science. 88:849-859.

Boligon, A.A., F. Baldi, and Albuquerque, L.G. 2011. Genetic parameters and relationships between growth traits and scrotal circumference measured at different ages in Nellore cattle. Genetics and Molecular Biology. 34(2) 225-230.

Coffey, M. P., J. Hickey, and Brotherstone, S. 2006. Genetic aspects of growth of Holstein-Friesian dairy cows from birth to maturity. Journal of Dairy Science. 89:322-329.

Dawson, W. M., R. W. Phillips, and Black, W. H. 1947. Birth Weight as a Criterion of Selection in Beef Cattle. Journal of Animal Science. 6(3): 247-257.

Dingwell, R.T., M. M. Wallace, C. J. McLaren, C. F. Leslie and Leslie, K. E. 2006. An evaluation of two indirect methods of estimating body weight in Holstein calves and heifers. Journal of Dairy Science. 89:3992-3998

Ghoraishy S. H., and Rokouei, M. 2013. Impact of birth weight of Iranian Holstein calves on their future milk production and reproductive traits. Journal of Livestock Science and Technologies 1:39-44.

Hamed, M . N . F., and El-Moghazy, M . M. 2015. Influence of sex and calf weight on milk yield and some chemical composition in the Egyptian buffalo's. Journal of Animal and Veterinary science 2:22- 27.

Jozica, J., M. Tadej, M. and Martina, K. 2012. Serum immunoglobulin (IgG, IgM, $\operatorname{IgA}$ ) concentration in cows and their calves. 20th Int. Symp. "Animal Science Days", Kranjska gora, Slovenia, Sept. 19th-21th, ACTA AGRIC. SLOV.3:295-298

Karna, D., G. L. Koul, and Bisht, G. 2001. Birth weight, morphometry and relative gain in body weight of Cheghu kids. The Indian journal of animal sciences. 71. 180-182.

Kashoma, I.P.B., C. Luziga, C. W. Werema, G. A. Shirima, and Ndossi. D. 2011. Predicting body weight of Tanzania 
shorthorn zebu cattle using heart girth measurements. Livst Res Rural Dev 23:94.

Lesosky, M., S. Dumas, I. Conradie, I. G. Handel, A. Jennings, S. Thumbi, P. Toye, and Bronsvoort B. M. C. 2012. A live weight-heart girth relationship for accurate dosing of east African shorthorn zebu cattle. Trop Animal Health and Production 45:311-316.

Lukuyu, M.N., J. P. Gibson, D.B. Savage, A. J. Duncan, F. D. N. Mujibi, and Okeyo, A.M. 2016. Use of body linear measurements to estimate liveweight of crossbred dairy cattle in smallholder farms in Kenya. SpringerPlus. 5:63.

Machila, N., E. M. Fevre, I. Maudlin, and Eisler, M.C. 2008. Farmer estimation of live body weight of cattle: implications for veterinary drug dosing in East Africa. Prev Vet Med. 87:394-403.

Musa, A.M., K. M. Elamin, S.A. Mohammed, and Abdalla, H.O. 2011. Morphometric traits as indicators for body weight in Sudanese Kenana cattle. Online J Anim Feed Res 1:218-222.

Rahbar, R., R. Abdullahpour, and SadeghiSefidmazgi, A. 2016. Effect of Calf Birth Weight on Milk Production of Holstein Dairy Cattle in Desert Climate. J Anim Behav Biometeorol. 4(3) p.65-70.

Obike, O. M., S. N. Ibe, and Oke, U. K. 2010. Estimation of pre and post-weaning body weight of rabbit in humid tropical environment using linear body measurement. American- Eurasian journal of Agriculture and environmental Science. (4): 440-444.

Ozkaya, S and Bozkurt, Y. 2009. The accuracy of prediction of body weight from body measurements in beef cattle. Archiv Tierz. 52:371-377.

Bahashwan, S., 2014. Application of Morphometric Traits for Live Body Weight Estimation in Dhofari Calves. International Journal of Scientific Research in Agricultural Sciences, 1(5), pp. 90-96.

Touchberry, R.W., And Lush, L.W. 1998. The Accuracy of Linear Body Measurements of Dairy Cattle. Iowa Agricultural Experiment Station, Ames.

Ulutas, Z ., I. A. Dewi, and Saatci, M. 2002. Genetic parameters of weights, ultrasonic muscle and fat depths, maternal effects and reproductive traits in Welsh Mountain sheep. Animal Science. 74: 399-408.

Yakubu, A. and Mohammed, G.L., 2012. Application of path analysis methodology in assessing the relationship between body weight and biometric traits of Red Sokoto goats in northern Nigeria. Biotechnology in Animal Husbandry. 28(1): 107-117.

\section{How to cite this article:}

Sikander Shabab Khan, Triveni Dutt, Amit Kumar, Brijesh Patel, Mukesh Singh, Pratik R. Wankhade, Upender Singh and Gaur. G. K. 2020. Body Morphometry in Relation to Season, Sex and Body Weight in Vrindavani Calves. Int.J.Curr.Microbiol.App.Sci. 9(05): 1223-1230. doi: https://doi.org/10.20546/ijcmas.2020.905.136 